\title{
Realisasi Kinerja Tenaga Administrasi Sekolah dalam Peningkatan Pelayanan
}

\author{
Mohamad Muspawi; Hafizahtul Robi’ah
}

\author{
Universitas Jambi \\ Jl. raya Jambi-Muara Bulian KM. 15 Mendalo Indah, Muaro Jambi, Jambi, Indonesia \\ muspawi01@gmail.com
}

Article received: February 2020; revised : June 2020 ; accepted : July 2020

DOI : 10.17977/um025v4i32020p232

\begin{abstract}
This research aims to find out the efforts of administrative staff in improving the quality of school services in SMP Negeri 8 Jambi City, and to find out the supporting and inhibiting factors in improving the quality of services at the school. Using descriptive qualitative methods. The subjects of the study were the school principal, the head of the administrative staff and the school administrative staff. Data obtained by interview, observation, documentation. All data were analyzed with a descriptive analysis approach. The results showed: (1) The efforts of administrative staff in improving the quality of school services in SMP Negeri 8 Jambi City were carried out in a systematic process, namely the management of school administrative staff involving teachers and staff to hold joint meetings in order to submit school service reports. This effort was made in accordance with aspects of school needs. (2) Supporting factors for improving the quality of this service is that each administrative staff has their own computer, then the available facilities, the principal always strives to meet the needs of the school. The obstacle faced by school administrative staff in improving the quality of school services is the lack of administrative personnel.
\end{abstract}

Keywords: school administration personnel; improving service quality

\begin{abstract}
Abstrak: Penelitian ini bertujuan untuk mengetahui upaya tenaga administrasi dalam meningkatkan mutu pelayanan sekolah di SMP Negeri 8 Kota Jambi, dan untuk mengetahui faktor pendukung dan penghambat dalam meningkatkan mutu pelayanan di sekolah tersebut. Menggunakan metode kualitatif deskriptif. Subjek penelitian adalah kepala sekolah, kepala tenaga administrasi dan staf tenaga administrasi sekolah. Data diperoleh dengan cara wawancara, observasi, dokumentasi. Semua data dianalisis dengan pendekatan analisis deskriptif. Hasil penelitian menunjukkan: (1) Upaya tenaga administrasi dalam meningkatkan mutu pelayanan sekolah di SMP Negeri 8 Kota Jambi dilakukan dengan proses yang sistematis, yaitu pengelola tenaga administrasi sekolah melibatkan para guru dan staf untuk mengadakan rapat bersama dalam rangka menyampaikan laporan pelayanan sekolah. Upaya ini dibuat sesuai dengan aspek-aspek kebutuhan sekolah. (2) Faktor pendukung peningkatan mutu pelayanan ini yaitu bahwa setiap tenaga administrasi sudah memiliki komputer sendiri, kemudian fasilitas yang tersedia, kepala sekolah selalu mengupayakan untuk memenuhi kebutuhan sekolah. Hambatan yang dihadapi tenaga administrasi sekolah dalam meningkatkan mutu pelayanan sekolah yaitu masih kurangnya jumlah personil tenaga administrasi.
\end{abstract}

Kata Kunci: tenaga administrasi sekolah; penigkatan mutu layanan 
Pendidikan dari dahulu sampai sekarang dipandang sebagai hal yang sangat penting dalam berbagai aspek kehidupan manusia. Sebab, sebagaimana yang dikatakan oleh Muspawi \& Claudia (2018: 180) pendidikan berperan sebagai salah satu wadah untuk membangun manusia yang berkualitas. Menurut UU RI No. 20 Tahun 2003 tentang Sistem Pendidikan Nasional, pasal 1 menjelaskan bahwa Pendidikan adalah usaha sadar dan terencana untuk mewujudkan suasana belajar dan proses pembelajaran agar peserta didik secara aktif mengembangkan potensi dirinya untuk memiliki kekuatan spiritual keagamaan, pengendalian diri, kepribadian, kecerdasan, akhlak mulia, serta keterampilan yang diperlukan dirinya, masyarakat, bangsa dan negara. Disamping itu lembaga-lembaga pendidikan telah banyak bermunculan, baik yang negeri maupun swasta, mulai yang berkualitas maupun yang kurang berkualitas.

Mutu adalah kemampuan yang (ability) yang dimiliki oleh sutau produk atau jasa (service) yang dapat dipenuhi kebutuhan atau harapan, kepuasan (satisfaction) pelanggan (customers) yang dalam pendidikan dikelompokkan menjadi dua, yaitu internal dan eksternal. Internal yaitu siswa atau mahasiswa sebagai pembelajar dan eksternal yaitu masyarakat dan dunia industri. Mutu tidak berdiri sendiri artinya banyak faktor untuk mencapainya dan untuk memelihara mutu (Fatah, 2013: 2).

Setiap lembaga pendidikan dituntut untuk selalu meningkatkan mutunya. Hal itu disamping memenuhi harapan masyarakat juga memenuhi Peraturan Pemerintah Republik Indonesia Nomor 19 Tahun 2005 tentang Standar Nasional Pendidikan, Pasal 91 ayat 1 dan 2 menyatakan bahwa: "Setiap satuan pendidikan pada jalur formal dan nonformal wajib melakukan penjaminan mutu pendidikan sebagaimana dimaksud pada ayat (1) bertujuan untuk memenuhi atau melampaui Standar Nasional Pendidikan. Kebermutuan suatu sekolah terlihat dari sejumlah ciri yang menyertai baik dari masukan (input), proses, maupun hasil (output). Sekolah dikatakan bermutu apabila memenuhi beberapa karakteristik diantaranya memiliki visi dan misi yang jelas, memiliki kepala sekolah yang profesional, memiliki guru yang profesional, memiliki lingkungan sekolah yang kondusif untuk belajar, memiliki kurikulum yang luas dan berimbang, tinggi dalam melibatkan masyarakat untuk ikut serta mengelola sekolah (Triatna, 2015: 53).

Lembaga sekolah merupakan sarana pendidikan yang pada dasarnya adalah bertujuan untuk menjadikan sumber daya manusia yang bermoral dan berakhlak, atas dasar yang berfondasikan pada tujuan dasar negara itulah maka lembaga pendidikan didirikan dan diolah sedemikian rupa agar menjadi penunjang untuk menghasilkan atau melahirkan insan-insan yang bermoral sesuai dengan kepribadian, karakter bangsa Indonesia pada khususnya. Untuk mencapai pendidikan yang bermutu tentu diperlukan iklim sekolah yang mendukungnya. Keberhasilan sebuah sekolah dalam mencapai tujuannya sangat dipengaruhi oleh iklim sekolah. Salah satu unsur iklim sekolah tersebut adalah pelaksanaan administrasi sekolah yang efektif.

Pembicaraan mengenai administrasi sekolah merupakan pembicaraan yang cukup penting, mengingat bahwa kelancaran pelaksanaan kegiatan belajar mengajar akan tercapai jika ditunjang oleh pelaksanaan administrasi sekolah yang baik. Maka wajar jika mengenai administrasi sekolah ini telah banyak diteliti oleh para peneliti, antara lain Fitriani (2014) dengan judul "Kinerja Tenaga Administrasi Sekolah di SMA Negeri 1 Kasihan dan SMA Muhammadiyah 1 Bantul". Wiyanta (2016) dengan judul "Peran Kepala Tata Usaha dalam Meningkatkan Kinerja Tenaga Kependidikan di SMA Negeri 1 Pleret Bantul Yogyakarta". Zakhiroh (2013) dengan judul "Pengaruh Kinerja Tenaga Administrasi Sekolah Terhadap Kualitas Layanan Administrasi Non Akademik"

Oleh karena itu, administrasi sekolah merupakan hal yang perlu dibenahi dalam rangka meningkatkan mutu pendidikan di sekolah-sekolah. Administrasi ialah sebagai suatu kegiatan atau usaha yang membantu, melayani, mengarahkan atau mengatur semua kegiatan di dalam mencapai suatu tujuan. Dengan demikian pengertian administrasi sekolah secara luas adalah seluruh rangkaian perbuatan atau kegiatan dari sekelompok orang yang bekerjasama dalam suatu sekolah untuk mencapai tujuan yang telah ditentukan dari sekolah/madrasah tersebut (Gozali \& Syamsuddin, 1997: 3). Atau dengan kata lain administrasi sekolah dapat didefinisikan sebagai aktifitas yang sistematis oleh tim yang ditugaskan sekolah dalam rangka mencapai tujuan yang telah ditetapkan. 
Tenaga administrasi sekolah menurut Zulkarnain \& Sumarsono (2018) adalah tenaga kependidikan yang bertugas memberikan dukungan layanan administrasi guna terselenggaranya proses pendidikan di sekolah. Mereka merupakan non teaching staff yang biasa dikenal dengan sebutan staf tata usaha (TU). Tata usaha sekolah juga berperan aktif dalam memberikan pelayanan administrasi kepada seluruh pihak yang berkepentingan. Kedudukan dan peran tenaga administrasi yang begitu penting dalam pengelolaan suatu sekolah sehingga pemerintah melalui Permendiknas Nomor 24 Tahun 2008 menetapkan standar tenaga administrasi sekolah. Standar ini mengatur tentang kualifikasi dan kompetensi minimal yang harus dipenuhi oleh seorang tenaga administrasi sekolah. Sama seperti halnya dalam sebuah sekolah yang sangat membutuhkan sumber daya manusia untuk meningkatkan mutu sekolah tersebut. Tidak hanya guru atau pengajar tetapi juga tenaga administrasi dalam upaya menunjang mutu pendidikan yang berkaitan dengan proses pendidikan salah satunya adalah dengan meningkatkan kualitas administrasi sekolah. Untuk mengefektifkan administrasi sekolah diperlukan adanya tenaga yang profesional di bidang administrasi sekolah.

Berdasarkan studi pendahuluan yang peneliti lakukan di SMP Negeri 8 Kota Jambi, diketahui jumlah personil tenaga administrasi di SMP Negeri 8 Kota tersebut berjumlah 5 orang, jumlah itu tentu kurang jika dilihat dari data Peraturan Menteri Pendidikan Nasional No. 24 Tahun 2008 tentang Standar Kinerja Tenaga Administrasi Sekolah/Madrasah seharusnya 8 orang.

Berdasarkan observasi awal penulis menemukan kinerja tenaga administrasi belum maksimal dengan bukti sebagai berikut: pekerjaan tenaga administrasi yang masih bersifat teknis yaitu menumpuknya pekerjaan yang harus dikerjaan oleh pegawai administrasi sekolah satu pekerjaan belum selesai sudah ada pekerjaan lain yang datang dan harus segera diselesaikan. Tugas yang sering diberikan yaitu tugas yang berada di luar dari tupoksi, seperti menyalin instrument guru, menyalin PKG dan kinerja guru sesuai dengan waktu yang sudah ditentukan. Dan penelitian ini bertujuan untuk mendeskripsikan bentuk kinerja yang dimiliki oleh tenaga administrasi sekolah di SMP Negeri 8 Kota Jambi dalam meningkatkan mutu sekolah, serta faktor pendukung dan penghambat tenaga administrasi dalam meningkatkan mutu sekolah.

\section{METODE}

Penelitian ini menggunakan pendekatan deskriptif kualitatif dengan jenis penelitian studi kasus (case study). Creswell, (2012:4) menyatakan bahwa metode kualitatif merupakan metode-metode untuk mengeksplorasi dan memahami makna yang oleh sejumlah individu atau sekelompok orang dianggap berasal dari masalah sosial atau kemanusiaan. Studi kasus yang di ambil adalah mengenai kinerja tenaga administrasi sekolah di SMP Negeri 8 Kota Jambi, yang beralamat di Jalan Sunan Giri RT 6 Simpang III Sipin Kota Jambi, telah dilaksanakan dari bulan Januari 2019 hingga bulan Mei 2019. Berikutnya, berkenaan pemilihan sumber data berupa subjek atau sampel manusia, penulis lakukan secara purposif yang dijelaskan oleh Lincoln \& Guba sebagaimana dikutif oleh (Moleong, 2010), bahwa peneliti mengawali dari asumsi konteksnya sendiri, dan bahwa peneliti memiliki kaitan yang cukup erat dengan faktor-faktor kontekstual yang ada.

Subjek penelitian berdasarkan prosedur sampling adalah kepala sekolah berjumlah 1 orang, kepala tata usaha sekolah berjumlah 1 orang, serta staf tenaga administrasi berjumah 4 orang. Dalam hal ini kepala tata usaha ditetapkan sebagai key informan. Penulis telah menyusun dan memalui serangkaian tahapan, yakni mulai dari: (1) Tahap persiapan, yaitu melakukan penelusuran terhadap sejumlah literatur yang relevan, menjajaki lokasi penelitian, mengidentifikasi data awal yang dibutuhkan, menyusun dan melakukan pengajuan proposal. (2) Tahap pelaksanaan, yaitu melakkan serangkaian data penelitian, mengolah data yang telah terkumpul, menganalisis data serta melakukan pemaknaan dalam pembahasan penelitian, dan diikuti dengan penyusunan laporan awal. (3) Tahap penyusunan laporan akhir penelitian, yaitu melakukan berbagai persiapan seminar dan melaksanakan seminar hasil penelitian, melakukan serangkaian perbaikan dan menyusun laporan akhir, dan menyerahkan laporan akhir ke pihak terakit. 
Pengumpulan data dilakukan dengan menggunakan teknik observasi, wawancara, serta dokumentasi. Observasi dalam penelitian ini digunakan untuk mengamati secara langsung kinerja tenaga administrasi sekolah yang ada di SMP Negeri 8 Kota Jambi. Wawancara digunakan untuk menggali informasi tentang kinerja tenaga administrasi sekolah. Sedangkan Teknik dokumentasi digunakan untuk mendapatkan data tentang profil sekolah serta dokumen-dokumen yang dibutuhkan. Langkah analisis data, yaitu menelaah, mereduksi data, menyajikan data, dan verifikasi data untuk mengambil kesimpulan. Selajutnya, teknik uji keabsahan data penulis lakukan dengan cara: wawancara secara mendalam, triangulasi, dan member checking.

\section{HASIL DAN PEMBAHASAN}

\section{Kinerja Tenaga Administrasi SMP Negeri 8 Kota Jambi}

Administrasi kesiswaan yang dilaksanakan oleh tenaga administrasi sekolah di SMP Negeri 8 Kota Jambi pencatatan siswa masuk sampai keluar, membuat data siswa dan juga pencatatan siswa pada buku induk sekolah. Administrasi kesiswaan yang dilaksanakan oleh tenaga administrasi sekolah di SMP Negeri 8 Kota Jambi adalah memproses siswa masuk sampai keluar dimulai dari pendaftaran, pencatatan calon siswa baru, pembagian siswa dalam kelas, pencatatan buku induk sekolah, daftar peserta UN dan dinayatakan lulus/keluar dari sekolah. Administrasi kesiswaan SMP N 8 Kota Jambi juga belum sepenuhnya terlaksana, yang belum terlaksana yaitu membuat data statistik peserta didik, dalam membuat data statistik peserta didik ini pegawai tenaga administrasi di bidang kesiswaan ini tidak ada yang bisa membuatnya karena terlalu susah.

Pelaksanaan administrasi kepegawaian di SMP Negeri 8 Kota Jambi yaitu mencatat data pendidik maupun tenaga kependidikan sekolah pada buku induk pegawai sekolah. Administrasi kepegawaian SMPN 8 Kota Jambi belum sepenuhnya terlaksanakan, yang belum terlakasanakan yaitu, memproses kepangkatan, mutasi, dan promosi pegawai. Karena staf tenaga administrasi kepegawaian tidak bisa membantu dalam memproses kepangkatan kepegawaian.

Pelaksanaan administrasi keuangan di SMP Negeri 8 Kota Jambi yaitu pengelolaan keuangan sekolah dari menyimpan, mengeluarkan uang sekolah. Administrasi keuangan sekolah yang dilaksanakan tenaga administrasi di SMP Negeri 8 Kota Jambi sudah terlaksana semuanya dari menyusun anggaran, pembukuan dari penerimaan dan pengeluaran uang.

Pelaksanaan administrasi sarana dan prasarana di SMP Negeri 8 kota Jambi yaitu melaksanakan kegiatan urusan menerima/pengeluaran, mencatat, memelihara dan menginventarisasikan barang milik sekolah. Administrasi sarana dan prasarana sekolah yang dilaksanakan tenaga administrasi di SMP Negeri 8 Kota Jambi belum sepenuhnya terlaksana, karena dalam uraian tugas tersebut yang belum terlaksana yaitu melaksanakan penghapusan sarana dan prasarana.

Pelaksanaan administrasi hubungan sekolah dan masyarakat di SMP Negeri 8 Kota Jambi meliputi pelaksanaan kegiatan yang berhubungan dengan orang tua, wali kelas, dan lingkungan. Kinerja tenaga administrasi hubungan masyarakat dan sekolah meliputi kegiatan membuat dan mengedarkan surat kepada pihak luar sekolah dan pihak yang berkepentingan seperti dinas pendidikan dan wali murid.

Pelaksanaan administrasi persuratan dan pengarsipan oleh tenaga administrasi sekolah di SMP Negeri 8 Kota Jambi meliputi kegiatan persuratan surat masuk maupun keluar, menyampaikan undangan atau edaran kepada guru dan pegawai, mengisi kartu disposisi dan menyampaikannya terhadap kepala sekolah, serta melayani legalisir. 


\section{Upaya Tenaga Administrasi dalam Meningkatkan Mutu Pelayanan Sekolah}

Upaya yang dilakukan oleh tenaga administrasi dalam meningkatkan mutu pelayanan di SMP Negeri 8 Kota Jambi meliputi perencanaan, pelaksanaan dan evaluasi. Perencanaan tenaga administrasi SMP Negeri 8 Kota Jambi untuk mencapai sutau sekolah harus memiliki suatu tahap dimana tahap itu adalah perencanaan, dimana perencanaan tersebut yaitu pengelola bagian tenaga administrasi sekolah melibatkan para guru dan staf untuk mengadakan rapat bersama dalam rangka menyampaikan laporan terhadap pelayanan sekolah yang harus diperbaiki maupun diperbaharui oleh sekolah.

Pelaksanaan tenaga administrasi SMP Negeri 8 Kota Jambi dalam kaitannya dengan peningkatan mutu pelayanan sekolah yaitu dengan pembagian di masing-masing bidangnya, masing-masing tenaga administrasi mampu mengerjakan tugasnya dengan baik dan bertanggung jawab supaya kelancaran sekolah berjalan dengan baik untuk meningkatkan mutu pelayan sekolah.

Upaya tenaga administrasi dalam meningkatkan mutu pelayanan sekolah yaitu dengan cara perencanaan, pelaksanaan, mengevaluasi, mutu pelayanan sekolah adalah nilai dari sekolah itu sendiri, untuk mencapai suatu sekolah harus memiliki suatu tahap dimana tahap itu adalah proses untuk mencapai mutu pelayanan sekolah. Serta dibutuhkan kompetensi dan keterampilan yang menunjang di bidang administrasi, sebagai tenaga administrasi dalam proses pengelolaan sangat diperlukan demi terciptanya sekolah yang bermutu. Berkenan dengan hal tersebut upaya tenaga administrasi sekolah sangatlah penting untuk mendukung kelancaran dan kesuksesan tata administrasi sekolah. Terciptanya mutu sekolah yang baik tidak lepas dari peran tenaga administrasi, dalam hal ini kepuasan yang dirasakan pelanggan bisa menjadi penilaian mutu sekolah.

\section{Faktor Pendukung dan Penghambat Tenaga Administrasi dalam Meningkatkan Mutu Pelayanan Sekolah}

Berdasarkan pemaparan dan hasil wawancara dari pihak kepala sekolah dan kepala tenaga administrasi dan stafnya mengungkapkan bahwa, untuk mendukung kelancaran kegiatan kinerja tenaga administrasi dalam meningkatkan mutu pelayanan sekolah kepala sekolah berangsur memenuhi kebutuhan tenaga administrasi, kemudian didukung oleh tenaga administrasi yang masing-masing sudah memiliki komputer. Selain faktor pendukung ada maka ada pula faktor penghambat yaitu kurangnya tenaga administrasi yang berstatus Negeri atau PNS dan juga masih kurang pelatihan atau diklat untuk tenaga administrasi.

Kegiatan perencanaan yang baik tentu diawali dengan suatu perencanaan yang matang dan baik. Supaya dalam melaksanakan kegiatan sesuai dengan tujuan yang telah di tetapkan secara efektif dan efesien. Menurut Bafadal (2003: 26) perencanaan merupakan suatu proses memikirkan dan menetapkan kegiatan-kegiatan atau program-program yang akan dilakukan di masa datang untuk mencapai tujuan tertentu. Perencanaan tenaga administrasi di SMP Negeri 8 Kota Jambi selalu mengedepankan perencanaan dan melihat kebutuhan yang ada. Baik kebutuhan pelanggan/ siswa maupun pendidikan dan juga melakukan pemeriksaan atau pengecekan atas proses pelayanan yang telah lalu, serta menambahnya sesuai kebutuhan di sekolah tersebut.

Selanjutnya menurut Bafadal (2003: 26) perencanaan peningkatan mutu pelayanan juga harus memperhatikan beberapa aspek yaitu: apa yang dilakukan, apa yang harus dilakukan, kapan dilakukan, dimana akan dilakukan, bagaimana melakukan, dan apa saja yang diperlukan agar terciptanya tujuan dapat maksimal. Perencanaan tenaga administrasi yang ada di SMP Negeri 8 Kota Jambi dapat peneliti analisis bahwa, perencanaan tenaga administrasi yang diterapkan dilakukan dengan bermusyawarah dan terkoordinir oleh pengelola tenaga administrasi yaitu Kepala Tenaga administrasi dengan para guru dan staf sekolah dalam agenda rapat tahunan. Sebelum melakukan perencanaan, diadakan pengecekan layanan agar dalam merencanakan peningkatan layanan bisa berjalan dengan efektif dan efisien.

Peningkatan layanan sesuai dengan perencanaan yang telah ditentukan dalam penyusunan program dan anggaran sekolah. Prosedur dalam peningkatan layanan terdiri dari perencanaan, pelaksanaan dan pelaporan. Proses perencanaan peningkatan layanan dilakukan oleh pengelola tenaga administrasi 
dengan cara melakukan analisis kebutuhan pelanggan dan pendidikan disetiap akhir semester. Setelah itu, pengelola tenaga administrasi bertanggung jawab membuat data pengajuan kebutuhan pelanggan dan selalu berkoordinasi dengan kepala sekolah, kemudian pengelola beserta kepala sekolah mengidentifikasi layanan yang dibutuhkan.

Pelaksanaan peningkatan layanan di SMP Negeri 8 Kota Jambi ialah dengan cara: data kebutuhan pelanggan disetujui oleh kepala sekolah, kemudian melaksanakan rapat pemilihan pengembangan pelayanan. Setelah disetujui, pengelola melaksanakan pengembangan pelayanan yang telah direncanakan. Pelaporan pelayanan ialah pengecekan terhadap pelayanan yang sudah diberikan, apabila ada yang tidak sesuai, maka layanan akan dilakukan perbaikan. Kemudian apabila layanan sudah sesuai, maka pengelola tata usaha melaporkan kepada kepala sekolah.

Berdasarkan data tersebut, aspek perencanaan pelayanan yang dilaksanakan oleh tenaga administrasi di SMP Negeri 8 Kota Jambi secara umum dapat dikatakan sesuai dengan rencana, yakni mulai dari bermusyawarah untuk menentukan pelayanan, perbaikan atau perbaharuan, pengecekan pelayanan hingga pengembangan pelayanan, serta mengadakan perbaikan pelayanan secara langsung apabila proses layanan berkaitan dengan kegiatan sehari-hari. Akan tetapi secara khusus, tidak menutup kemungkinan adanya kendala dalam perencanaan pelayanan, seperti pengembangan layanan yang berkaitan dengan sarana dan prasarana sekolah tidak dapat merealisasikan secara langsung karena menunggu dana dari pemerintah daerah.

Pelaksanaan adalah upaya untuk mengarahkan tenaga kerja serta mendayagunakan fasilitas yang ada. Salah satu upaya tersebut ialah pengembangan dan pemeliharaan. Pengembangan ialah sebuah kegiatan menambah atau merubah sesuatu agar lebih meningkat dan baik lagi. Berdasarkan temuan data hasil observasi yang peneliti lakukan di SMP Negeri 8 Kota Jambi bahwa pengembangan dan pemeliharaan pelayanan dimaksudkan agar proses pelayanan senantiasa mempunyai peningkatan dan berjalan dengan baik. Kemudian untuk hal apa saja yang perlu ditingkatkan dalam pelayanan, pihak tata usaha sekolah mengadakan pertemuan atau rapat dengan wali murid. Hal ini dilakukan untuk mengetahui sampai mana kinerja pelayanan sekolah.

Disamping itu, mengenai ketersediaan sarana prasarana, sekolah senantiasa berupaya untuk meningkatkan kualitas pelayanan pendidikan terhadap siswanya. Hal ini dapat dilihat dari upaya sekolah untuk menyediakan sarana prasarana yang sesuai dengan kebutuhan. Pendistribusian yang diterapkan di SMP Negeri 8 Kota Jambi kegiatan pendistribusian berjalan dengan cukup baik. Pelaksanaan tugas tenaga administrasi tentu mengarah kepada tujuan dari suatu administrasi itu sendiri, yang mana menurut Sergiovanni dan Carver dalam Daryanto (2008:17) menyebutkan empat tujuan administrasi yaitu: efektivitas produksi, efisiensi, kemampuan menyesuaikan diri, dan kepuasan kerja.

Kegiatan evaluasi pelayanan tenaga administrasi sekolah yaitu dengan mengawasi atau melihat secara langsung proses pelayanan. Jika tidak memenuhi syarat-syarat tertentu maka pelayanan tersebut akan dilakukan perbaikan. Evaluasi dilakukan minimal dua kali setiap enam bulan (satu semester) sekali, dengan cara melibatkan para guru dan staf untuk melaporkan berkaitan dengan layanan yang perlu diperbaiki maupun diperbaharui. Kegiatan evaluasi dengan cara memonitoring secara langsung, jika pelayanan masih layak dan baik maka akan dilakukan pemeliharaan dan peningkatan, akan tetapi bila ada komplain tentang pelayanan, maka akan dilakukan perubahan dan peningkatan. Perubahan dan peningkatan merupakan kegiatan mengubah dan menambah atau mengurangi berdasarkan pedoman yang berlaku. Perubahan dan peningkatan dilakukan supaya kualitas atau mutu pelayanan tetap terjaga.

Kinerja tenaga administrasi dalam meningkatkan mutu pelayanan sekolah tentu harus ada faktor pendukungnya. jumlah tenaga administrasi di SMP Negeri 8 Kota Jambi yang berjumlah 5 orang. Tenaga administrasi berusaha untuk mengoptimalkan setiap proses pengelolaan, kemudian didukung oleh setiap tenaga yang sudah memiliki komputer sendiri, sehingga cukup membantu kinerja tenaga administrasi dalam meningkatkan mutu pelayanan sekolah.

Kepala SMP Negeri 8 Kota Jambi telah berupaya memenuhi kebutuhan sekolah secara berangsurangsur, SMP Negeri 8 Kota Jambi masih menemui banyak permasalahan. Permasalahan ini muncul karena masih kurangnya tenaga administrasi yang berstatus negeri, sehingga ada banyak tumpang tindih 
pekerjaan atau rangkap jabatan. Dan kurangya Diklat untuk pegawai tenaga administrasi berpengaruh terhadap kegiatan tenaga administrasi yang menjadi tidak optimal. Menurut Mutohar (2013:129) karakteristik peningkatan manajemen mutu sekolah dapat diketahui dari bagaimana sekolah dapat mengoptimalkan kinerja oraganisasi sekolah, proses pembelajaran, pengelolaan sumber daya dan administrasi. Pemberian diklat kepada para teaga administrasi memang sangat penting, dengan hal itu diharapkan tenaga administrasi dapat memenuhi kompetensi mereka, sebagaimana yang dikatakan oleh Syaefudin (2003: 100) kompetensi tenaga administrasi sekolah merupakan kemampuan untuk melaksanakan tugas, peran dan kemampuan mengintegrasikan pengetahuan yang didasarkan pada pengalaman dan pembelajaran yang dilakukan dalam pelaksanaan pekerjaannya yang dituntut dalam kecakapan teknis operasional atau teknis administrasi di sekolah.

Upaya tenaga administrasi dalam meningkatkan mutu pelayanan sekolah di SMP Negeri 8 Kota Jambi masih terdapatnya beberapa hambatan yaitu: (1) Sumber daya manusia untuk tenaga administrasi masih kurang khususnya yang berstatus pegawai negeri sipil. (2) Kurangnya pelatihan atau diklat untuk tenaga administrasi sehingga untuk pengelolaan sistem IT belum bisa optimal. Strategi yang dilakukan untuk mengatasi hambatan-hambatan tersebut ialah tenaga administrasi yang PNS mau tidak mau merangkap jabatan untuk mengisi kekosongan yang ada, strategi selanjutnya tenaga administrasi yang berpengalaman memberikan arahan, dan diharapkan sesama tenaga administrasi untuk saling sharing, dan mau belajar.

Mencermati apa yang telah dilakukan oleh tenaga administrasi sekolah di SMP Negeri 8 Kota Jambi, dapat dikatakan sejalan dengan temuan penelitian yang telah dilakukan oleh Hidayah \& Nurhikmahyanti (2014), yang berfokus pada (1) Peran tenaga administrasi sekolah di MAN 1 Kota Mojokerto; (2) Mutu pelayanan sekolah di MAN 1 Kota Mojokerjto; dan (3) Upaya-upaya dalam mengembangkan kualitas tenaga administrasi sekolah di MAN 1 Kota Mojoketo. Begitu juga dengan penelitian yang dilakukan oleh Linda (2017), yang berfokus pada (1) Gambaran kinerja pegawai tata usaha di SMP N 4 Lappariaja Kabupaten Bone (2) Faktor-faktor yang mempengaruhi kinerja pegawai kinerja pegawai tata usaha di SMP N 4 Lappariaja Kabupaten Bone.

\section{SIMPULAN DAN SARAN}

Berdasarkan hasil penelitian dapat disimpulkan bahwa upaya tenaga administrasi SMP Negeri 8 Kota Jambi dalam meningkatkan mutu pelayanan sekolah melalui tiga tahap yaitu: perencanaan kerja, pelaksanaan tugas rutin, dan evaluasi kegiatan. Sedangkan faktor pendukung dalam meningkatkan mutu pelayanan sekolah ini yaitu adanya sarana dan prasarana yang sudah sangat membantu dalam peningkatan mutu pelayanan sekolah yang baik dan kepala sekolah selalu mengupayakan untuk memenuhi kebutuhan sekolah, jika terjadi kekurangan terkait sarana prasarna, di penuhi secara berangsur. Sedangkan faktor penghambat yang dihadapi yaitu masih kurangnya tenaga administrasi khususnya yang PNS, hal ini menyebabkan rangkap jabatan, karena tenaga untuk penanggung jawab masih kurang. Kemudian kurangnya pelatihan ataupun diklat untuk tenaga administrasi, menjadi menyebabkan belum optimalnya pengelolaan sistem IT, terlebih lagi diera globalisasi, banyak aplikasi-aplikasi baru untuk menunjang kegiatan sekolah.

Saran kepada kepala sekolah agar selalu meningkatkan mutu tenaga administrasi dalam meningkatkan mutu sekolah. Kepada tenaga administrasi agar terus mencari dan mengembangkan strategi program yang sudah berjalan, sebaiknya ada penambahan jumlah pegawai tenaga administrasi agar kinerja tenaga administrasi yang dijalankan bisa optimal, serta pelayanan bisa menjadi lebih cepat. Serta kepada staf tenaga administrasi agar dapat melaksanakan tugasnya dengan baik agar lebih meningkatkan mutu pelayanan sekolah. 


\section{DAFTAR RUJUKAN}

Bafadal, Ibrahim. (2003). Manajemen Perlengkapan Sekolah. Jakarta: Bumi Aksara.

Creswell, J. W. (2012). Educational Research:Planning, Conducting, And Evaluating Quantitative And Qualitative Research. In Educational Research. https://doi.org/10.1017/CBO97811074 15324.004

Daryanto. (2008). Administrasi Pendidikan. Jakarta: Rineka Cipta.

Fatah, Nanang. (2013). Landasan Manajemen Pendidikan. Bandung: Remaja Rosdakarya.

Fitriani, Umi. (2014). Kinerja Tenaga Administrasi Sekolah di SMA Negeri 1 Kasihan dan SMA Muhammadiyah 1 Bantul. Skripsi. Yogyakarta: UNY

Gozali, Ahmad \& Syamsuddin BA. (1997). Administrasi Sekolah. Jakarta: Cahaya Budi.

Hidayah, S.P \& Nurhikmahyanti, D. (2014). Peran Tenaga Administrasi Sekolah Dalam Meningkatkan Mutu Pelayanan Sekolah Di Man 1 Kota Mojokerto: Jurnal Inspirasi Manajemen Pendidikan, Vol. 4 No. 4, April 2014: 152-162.

Linda. (2017) Kinerja Pegawai Tenaga Tata Usaha di SMP N 4 Lappariaja Kabupaten Bone. Skripsi. Makasar: UIN Alauddin

Moleong, Lexy. J. (2010). Metodologi Penelitian Kualitatif. Bandung: Remaja Rosdakarya.

Muspawi, Mohamad \& Claudia, Peavey Resa. (2018). Optimalisasi Pemanfaatan Sarana dan Prasarana Belajar di SMA Swasta Pelita Raya Kota Jambi. Jurnal Sains Sosio Humaniora. Universitas Jambi. Volume 2 Nomor 2 Desember 2018: 180-192.

Mutohar. (2013). Manajemen Pendidikan. Jakarta: Raja Grafindo Persada.

Peraturan Menteri Pendidikan Nasional No 242008 Tentang Standar Tenaga Administrasi Sekolah/Madrasah. Peraturan Pemerintah Republik Indonesia Nomor 19 Tahun 2005 tentang Standar Nasional Pendidikan.

Syaefudin, Aas. (2003). Administrasi Kepemimpinan dan Supervisi Kepemimpinan. Bandung: STIKIP Siliwangi. Triatna, Cepi. (2015). Pengembangan Manajemen Sekolah. Bandung: Remaja Rosdakarya.

UU RI No. 20 Tahun 2003 tentang Sistem Pendidikan Nasional.

Wiyanta, Hery. (2016). Peran Kepala Tata Usaha dalam Meningkatkan Kinerja Tenaga Kependidikan di SMA Negeri 1 Pleret Bantul Yogyakarta. Skripsi. Yogyakarta: UIN Sunan Kalijaga.

Zakhiroh. R. (2013). Pengaruh Kinerja Tenaga Administrasi Sekolah Terhadap Kualitas Layanan Administrasi Non Akademik. Didaktika, Jurnal Administrasi Vol. 17 No. 2 Februari 2013.

Zulkarnain, W., \& Sumarsono, R.B. 2018. Manajemen \& Etika Perkantoran Praktik Pelayanan Prima. Bandung: PT Remaja Rosdakarya. 